\title{
Histological study of tendon healing in malnourished Wistar rats treated with ultrasound therapy ${ }^{1}$
}

\author{
Estudo histológico da cicatrização tendínea em ratos Wistar \\ desnutridos tratados com ultra-som terapêutico
}

\author{
Paulo de Tarso Camillo de Carvalho ${ }^{2}$, Iandara Schettert Silva ${ }^{3}$, Filipe Abdalla dos Reis ${ }^{4}$, Ana Carulina Guimarães \\ Belchior $^{4}$, Ricardo Dutra Aydos ${ }^{5}$, Gilberto Gonçalves Facco ${ }^{6}$, Doroty Mesquita Dourado ${ }^{7}$
}

1. Department of Physiotherapy at the University for Development of the State and the Pantanal Region (UNIDERP), Campo Grande, Mato Grosso do Sul, Brazil.

2. PhD, Associate Professor of the Department of Physiotherapy, UNIDERP, Brazil.

3. PhD, Associate Professor of the Department of Veterinary, UNIDERP, Brazil.

4. Fellow Master degree, Assistant Professor of the Department of Physiotherapy, UNIDERP, Brazil.

5. PhD, Associate Professor of the Department of Surgery, Federal University of Mato Grosso do Sul, Campo Grande, Brazil.

6. Master, Associate Professor of the Department of Veterinary, UNIDERP, Brazil.

7. PhD, Associate Professor of the Department of Physiotherapy, UNIDERP, Brazil

\begin{abstract}
Purpose: To investigate the effects of therapeutic ultrasound on the healing of tendon injuries in malnourished rats. Methods: After the intended nutritional states had been attained, the animals $(\mathrm{N}=36)$ were distributed into three groups, named: $\mathrm{G} 1(\mathrm{~N}=12)$, control group; $\mathrm{G} 2(\mathrm{~N}=12)$, malnourished rats treated with $3 \mathrm{MHz}$ ultrasound at an intensity of $0.5 \mathrm{~W} / \mathrm{cm}^{2}$; and $\mathrm{G} 3(\mathrm{~N}=12)$, normal animals treated with $3 \mathrm{MHz}$ at $0.5 \mathrm{~W} / \mathrm{cm}^{2}$. The injuries were induced by means of an operation to expose the heel tendon and crush it using Allis forceps. Results: The data obtained relating to leukocyte counts, fibroblasts, vessel neoformation, fibrosis and collagen were subjected to statistical treatment using analysis of variance (ANOVA) and Student's t test. Results of $\mathrm{p}<0.05$ were obtained for fibrosis and collagen. Conclusion: The ultrasound was shown to be effective in repairing the tendon, even in malnourished animals whose healing process was retarded.
\end{abstract}

Key words: Ultrasonics. Malnutrition. Tendon Injury.

\section{RESUMO}

Objetivo: Investigar os efeitos do ultrassom terapêutico na cicatrização de lesões tendíneas em ratos desnutridos. Métodos: Após ser constatado o estado nutricional proposto, os animais $(\mathrm{N}=36)$ foram distribuídos em três grupos, denominados: $\mathrm{G} 1(\mathrm{~N}=12)$ grupo controle, $\mathrm{G} 2(\mathrm{~N}=12)$ desnutrido tratado com ultra-som $3 \mathrm{MHz}$ a $0,5 \mathrm{w} / \mathrm{cm}^{2}$ de intensidade e $\mathrm{G} 3(\mathrm{~N}=12)$ animais normais tratados com $3 \mathrm{MHz}$ a $0,5 \mathrm{w} / \mathrm{cm}^{2}$. As lesões foram induzidas através de procedimento operatório para exposição e esmagamento com pinça Allis, do tendão calcâneo. Resultados: Os dados obtidos em relação à quantidade de leucócitos, fibroblastos, neoformações de vasos, fibrose e colágeno foram submetidos ao tratamento estatístico pela análise de variância (ANOVA) e teste " $t$ ” obtendo-se $\mathrm{p}<0,05$ para fibrose e colágeno. Conclusão: O ultra-som mostrou-se eficaz no reparo tendíneo, mesmo nos animais desnutridos e com processo de cicatrização retardado.

Descritores: Ultra-som. Desnutrição. Traumatismos dos Tendões.

\section{Introduction}

Injuries to connective tissue caused by trauma or aging are very common, especially those in tendons ${ }^{1}$. According to Enwemeka ${ }^{2}$, primary healing of the tendon takes around six weeks to acquire the resistance needed to effectively transmit the force generated by a muscle. Because of the anatomical characteristics of tendons, there is great scope for delay in the tissue repair process, which can be made worse by factors of systemic origin, such as diabetes mellitus and malnutrition ${ }^{3}$. Malnutrition causes decreases in amino acids, carbohydrates, lipids, mineral salts and vitamins that are essential for energy source accumulation, cell proliferation, tensile strength development in wounds, collagen synthesis and connection between recently-formed chains. In short, protein-energy malnutrition causes poor maintenance of tissue repair and growth ${ }^{4}$. Nutritional deficiencies have a profound effect on the organism and also on the healing of wounds, altering tissue regeneration, inflammatory reactions and immunological function. Thus, they interfere in the principal stages in the healing process, by causing alterations in the protein synthesis process and stimulating greater collagen lysis ${ }^{4}$. A variety of therapeutic methods have already been utilized in attempts to accelerate the tissue repair process, to enable a return to morphological and functional normality in the tendon. Among these have been electrostimulation, low-intensity laser and therapeutic ultrasound ${ }^{2,5}$. 
Therapeutic ultrasound has been utilized for almost half a century for treating various pathological conditions, and large numbers of studies attempting to explain its effects have been published ${ }^{6}$. Among the various authors who have reported on this topic, the following studies can be cited, which demonstrated the stimulus from ultrasound in relation to angiogenesis ${ }^{6}$, increased blood circulation ${ }^{7}$, accelerated healing of ulcers ${ }^{8}$, accelerated repair of fractures with retarding of consolidation and pseudo-arthrosis ${ }^{9}$, accelerated activation of macrophages ${ }^{10}$ and healing of tendons ${ }^{11}$. While, on the one hand, there is high incidence of tendon injuries producing various degrees of incapacitation, on the other hand numerous tissue repair problems are inherent to diet, and more specifically proteinenergy malnutrition. Considering these together with the positive results from studies on the physiological effects of ultrasound on tissue repair, the objective of the present study was to investigate the efficacy of pulsed therapeutic ultrasound on tendon repair in animals subjected to proteinenergy restriction.

\section{Methods}

\section{Sample and experimental delineation}

Thirty-six male rats (Rattus norvegicus) of the albino Wistar lineage were utilized. Twenty-four of them, which made up Group 1 (G1) and Group 2 (G2), were taken off the mother's milk on the $26^{\text {th }}$ day of life and subsequently subjected to malnutrition by means of protein-poor feed containing $2 \%$ casein, for 21 days. The animals were kept confined in boxes at a constant room temperature $\left(24^{\circ} \mathrm{C} \pm\right.$ $2^{\circ} \mathrm{C}$ ) with adequate light (dark and light cycles of 12 hours each), at the central vivarium of the University for Development of the State and the Pantanal Region (UNIDERP). The 36 animals were distributed into three groups of 12 animals each. Group 1 (G1) was a control group that was subjected to malnutrition but not treated; Group 2 (G2) was subjected to malnutrition and then treated with ultrasound; and Group 3 (G3) consisted of normal animals treated with ultrasound. The groups were subdivided into three subgroups named A, B and C, with four animals in each, such that the subgroups G2A and G3A were treated until the third day, subgroups G2B and G3B were treated until the seventh day, and subgroups $\mathrm{G} 2 \mathrm{C}$ and $\mathrm{G} 3 \mathrm{C}$ were treated until the fourteenth day. All the experimental procedures were in conformity with the rules of the Brazilian College for Animal Experimentation (COBEA) and the Research Ethics Committee of the University for Development of the State and the Pantanal Region (UNIDERP).

\section{Production of the tendon injury}

Following dissociative anesthesia using ketamine (10 $\mathrm{mg} / 100 \mathrm{~g}$ of weight) together with xylazine $(2 \mathrm{mg} / 100 \mathrm{~g}$ of weight), by means of the intramuscular route and an aseptic technique, surgical access to the common heel tendon (Achilles heel) was obtained. Using gripping forceps of Allis type, a standard crushing injury was created in the middle third of the tendon, with the maximum clamping of the instrument for two minutes. After closing up the resected planes, the animals were returned to the boxes, where they remained for the duration of the experiment.

\section{Application of ultrasound}

Ultrasound equipment of frequency $3 \mathrm{MHz}$ was used, with a transducer of $0.2 \mathrm{~cm}^{2}$ in geometrical area. This was pulsed using a 1:5 scheme $(100 \mathrm{~Hz} ; 2 \mathrm{~ms}$ on and $8 \mathrm{~ms}$ off; $20 \%$ ) and intensity of $0.5 \mathrm{~W} / \mathrm{cm}^{2}$ SATA (spatial average temporal average). The animals in groups $\mathrm{G} 2$ and $\mathrm{G} 3$ received a daily application of ultrasound at the location of the injury, with the abovementioned intensity, for six minutes.

\section{Euthanasia}

The animals in the subgroups $\mathrm{A}, \mathrm{B}$ and $\mathrm{C}$ were submitted to euthanasia by ethylic ether inhalation until cardiorespiratory arrest, on the third, seventh and fourteenth days after starting the treatment, respectively. After certifying that the animals were dead, the whole heel tendon was extracted by sectioning at the origin and insertion points using a scalpel blade. The extracted tendon was then washed in physiological solution and then fixed using $10 \%$ formol, in preparation for histological analysis. Thin sections were cut and stained using hematoxylin-eosin (HE) and Masson's trichrome (MT).

\section{Statistical analysis}

The data obtained from the histopathological analysis were subjected to statistical treatment. In this, the delineation adopted was analysis of variance (ANOVA) and, for analysis of paired samples, Student's t test. The nullity hypothesis was set at a significance level of 0.05 or $5 \%(\mathrm{a} \leq 0.05)$.

\section{Results}

The semi-quantitative data obtained from the histological analyses were compared by means of statistical crosses between the three groups: G1, malnourished untreated; G2, malnourished and treated with ultrasound; and G3, normal treated, and between the treatment withdrawal date subgroups (3, 7 and 14 days after creating the injury) (Table 1). From the general means for the groups, comparisons between $\mathrm{G} 1, \mathrm{G} 2$ and $\mathrm{G} 3$ were made by means of analysis of variance (ANOVA test), and the following were observed: fibrosis, $p=0.7172(p>0.05)$; leukocytes, $\mathrm{p}=0.9475(\mathrm{p}>0.05)$; new vessels, $\mathrm{p}=0.6807(\mathrm{p}>0.05)$; fibroblasts, $\mathrm{p}=0.8668(\mathrm{p}>0.05)$; and collagen, $\mathrm{p}=0.8596$ $(p>0.05)$. In other words, none of these crosses presented statistically significant differences (Figures 1, 2 and 3). However, in the statistical comparison using Student's $\mathrm{t}$ test for paired samples between the collection days ( 3 vs. 7 vs. 14) for each element analyzed (i.e. fibrosis, leukocytes, new vessels, fibroblasts and collagen), two significant results were obtained. From the fibrosis analysis, the significant difference $\mathrm{p}=0.0206(\mathrm{p}<0.05)$ was obtained for 3 days vs. 7 days and for 3 days vs. 14 days. From the collagen analysis, the significant difference $p=0.0257(p<0.05)$ was 
obtained for 3 days vs. 7 days, and for 3 days vs. 14 days. Comparing the collection days, there were significant differences between the samples collected on the third day, between: fibrosis and leukocytes; leukocytes and fibroblasts; leukocytes and collagen; and new vessels and collagen. This comparison between paired samples was done using Student's t test, obtaining $\mathrm{p}=0.0073(\mathrm{p}<0.05)$.

TABLE 1 - Representation of the means obtained through semiquantitative analysis of the thin sections relating to the three groups: malnourished and untreated (G1), malnourished and treated (G2) and normal nutrition and treated (G3).

\begin{tabular}{|c|c|c|c|c|c|c|c|c|c|c|c|c|c|c|c|}
\hline \multirow[t]{2}{*}{ Days } & \multicolumn{3}{|c|}{ Fibrosis } & \multicolumn{3}{|c|}{ Leukocytes } & \multicolumn{3}{|c|}{ New Vessels } & \multicolumn{3}{|c|}{ Fibroblasts } & \multicolumn{3}{|c|}{ Collagen } \\
\hline & G1 & G2 & G3 & G1 & G2 & G3 & G1 & G2 & G3 & G1 & G2 & G3 & G1 & G2 & G3 \\
\hline 3 & 3.0 & 3.0 & 2.0 & 3.75 & 4.25 & 4.5 & 3.0 & 3.25 & 3.75 & 3.0 & 3.0 & 2.5 & 3.0 & 2.0 & 1.5 \\
\hline 7 & 3.75 & 3.75 & 3.5 & 3.25 & 3.25 & 4.0 & 3.75 & 3.5 & 3.75 & 3.75 & 3.75 & 3.5 & 3.75 & 4.25 & 3.25 \\
\hline 14 & 3.5 & 3.75 & 3.75 & 3.75 & 2.5 & 1.5 & 3.75 & 2.0 & 2.0 & 3.5 & 2.75 & 4.0 & 3.25 & 4.25 & 4.25 \\
\hline
\end{tabular}

*The data from the means were analyzed according to their grade: Intense -5 ; Frequent -4 ; Rare -3 ; Absent -1 .

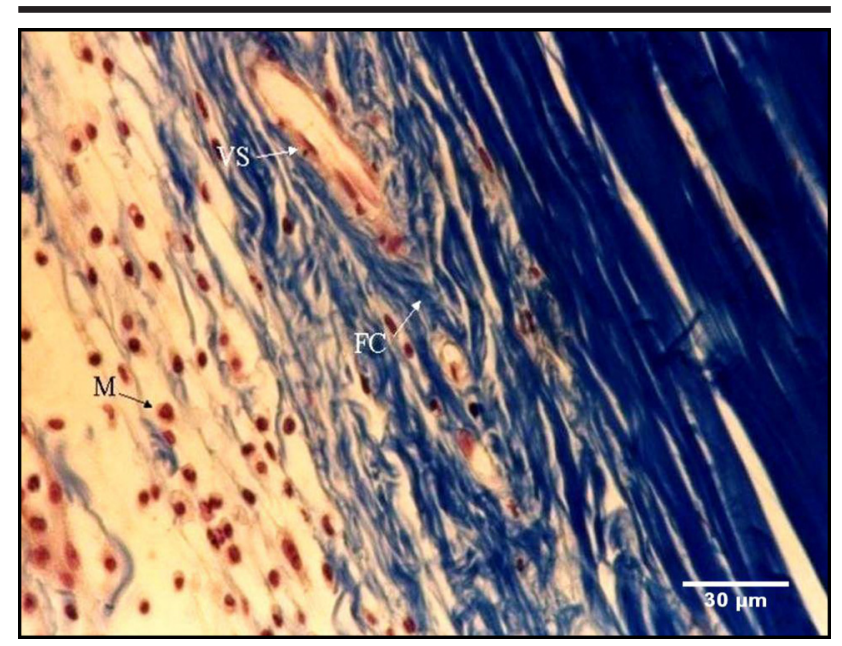

FIGURE 1 - Photomicrograph stained with Masson's trichrome, showing concentration of collagen fibers (FC) and blood vessels (VS) in group G1 animals (malnourished and not treated, after 14 days). $400 \mathrm{X}$ magnification.

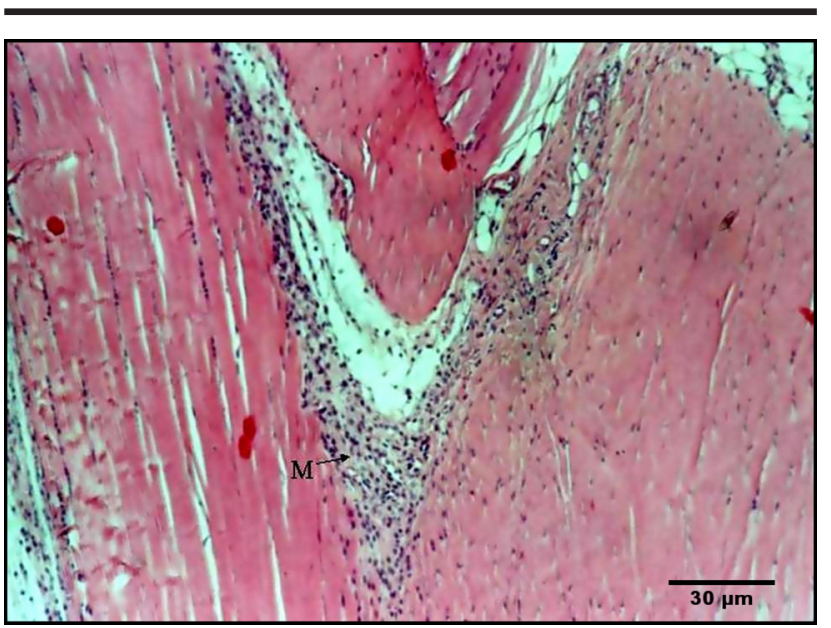

FIGURE 3 - Photomicrograph stained with hematoxylin-eosin, showing concentration of macrophages $(M)$ in group G2 animals (malnourished and treated for 7 days). 100X magnification.

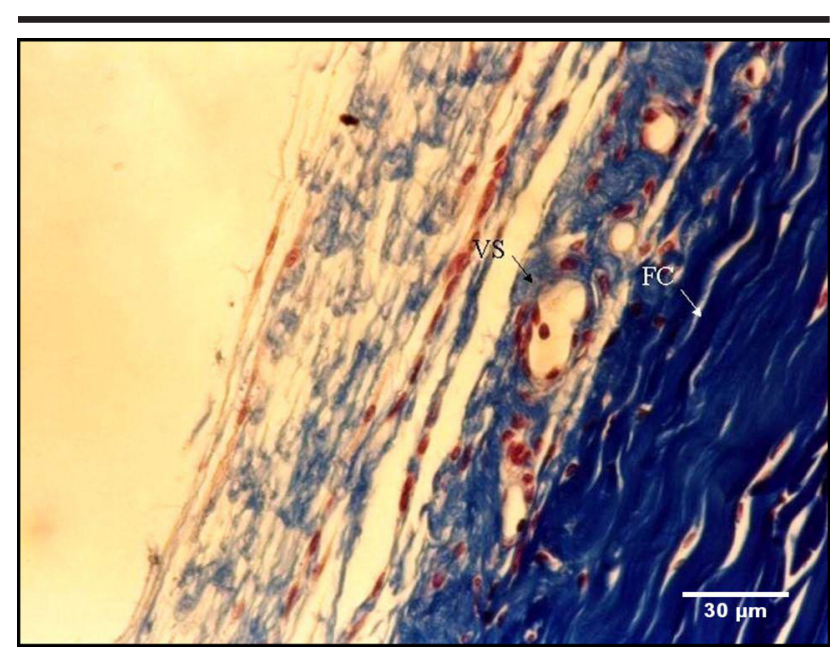

FIGURE 2 - Photomicrograph stained with Masson's trichrome, showing concentration of collagen fibers (FC), macrophages (M) and blood vessels (VS) in group G2 animals (malnourished and treated for 3 days). $400 \mathrm{X}$ magnification.

\section{Histopathological results}

In Group G1A (untreated and malnourished, three days after creating the injury), frequent activity of inflammatory cells (leukocytes and polymorphonuclear cells) close to the injured tissue was observed. There was inconsistent neoformation of blood vessels and rare presence of fibroblasts, collagen fibers and fibrosis. In Group G1B (untreated and malnourished, seven days), decreased numbers of leukocytes was observed, along with markedly increased vessel neoformation and greater production of collagen fibers and fibrosis, thus making fibroblasts more frequent than in the three-day group. The G1C sample (untreated and malnourished, 14 days) showed that the leukocytes that had been decreasing in numbers in relation to the three-day group had now surged back to be as great in numbers on the fourteenth day as on the third day. This led us to deduce that the animals that had been subjected to malnutrition and were untreated were more susceptible to infection. Nonetheless, the proliferation of neoformed 
vessels was maintained, as was the deposition of collagen fibers (Figure 2). In Group G2A (malnourished and three days of $20 \%$ ultrasound treatment at frequency of $3 \mathrm{MHz}$ and intensity of $0.5 \mathrm{~W} / \mathrm{cm}^{2}$ ), intense presence of leukocyte activity was observed, along with frequent angiogenesis and rare fibroblasts (Figure 1). In Group G2B (malnourished and treated for seven days), it was seen that, while the leukocyte activity had decreased slightly, there was significantly increased vessel neoformation and greater production of collagen than in the untreated group (Figure 3). In Group G2C (malnourished and treated for 14 days), the histopathological analyses showed that there had been considerable decreases in leukocyte activity and vessel neoformation, with greater presence of fibroblasts and increased collagen in comparison with the untreated group. It was found that the animals in Group G3A (normal nutrition and treated for three days) presented increased quantities of leukocytes and vessel neoformation, and decreased collagen, fibrosis and fibroblasts, in comparison with the G2A animals (malnourished and treated) (Figure 4). For the animals in Group G3B (normal and treated for seven days), it was found that the quantity of leukocytes and the vessel neoformation had undergone an increase, while the fibroblasts, fibrosis and collagen were decreased. In Group G3C (normal and treated for 14 days), it could be seen that the leukocyte activity and vessel neoformation had greatly diminished in comparison with the malnourished treated animals.

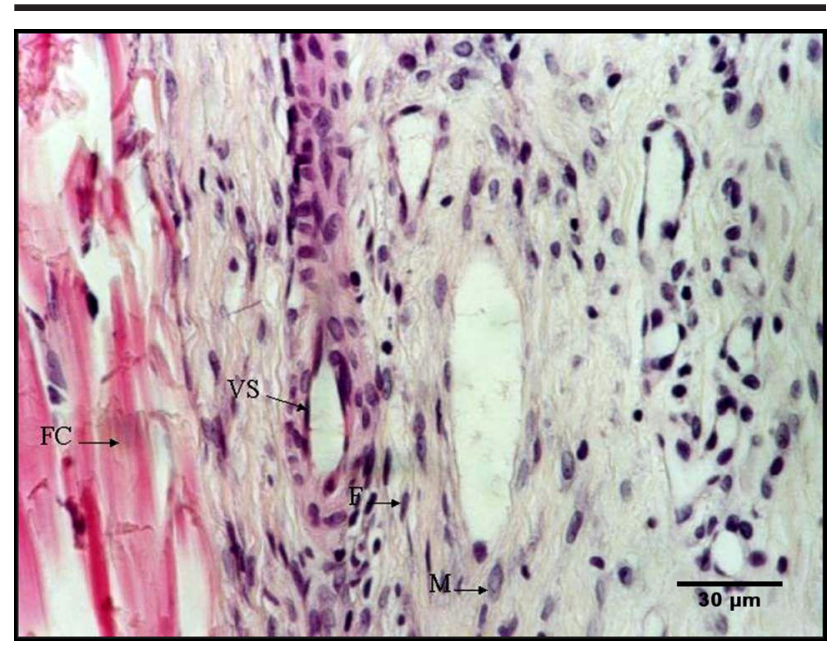

FIGURE 4 - Photomicrograph stained with hematoxylineosin, showing concentration of collagen fibers (FC), fibroblasts (F) and blood vessels (VS) in group G3 animals (normal nutrition and treated for 3 days). 400X magnification.

\section{Discussion}

Therapeutic ultrasound is one of the electrical therapeutic resources most utilized for the recovery of soft tissue such as muscles and tendons ${ }^{12}$. Several studies have been conducted to clarify the biophysical effects of ultrasound waves on biological tissue, but many doubts remain regarding the benefits that may arise from ultrasound.
Among the many studies carried out on the action of therapeutic ultrasound, a good proportion have focused on the healing of tendon injuries ${ }^{11,13}$. Some have shown that ultrasound therapy may act to stimulate the cells involved in the process, thus resulting in accelerated healing ${ }^{11,12}$, while others have shown harmful effects on the repair process ${ }^{13,14}$. There is therefore no consensus regarding the role of therapeutic ultrasound in the healing of tendons, such that new studies are justified. In the present study, it was decided to work with $20 \%$ ultrasound at a frequency of $3 \mathrm{MHz}$ and intensity of $0.5 \mathrm{~W} / \mathrm{cm}^{2}$, using a pulsed scheme. This made it possible to corroborate the studies that showed beneficial results and to expand such results, given that the same treatment was carried out on malnourished rats, when it is known that the nutritional state interferes directly in tissue repair, as stated by the authors of these studies ${ }^{15,16}$. Protein malnutrition has been associated with retarded healing caused by reduced production of fibroblasts, vessel neoformation and collagen synthesis, and also with lower capacity for tissue remodeling ${ }^{15,16}$. The pulsed mode of ultrasound therapy was chosen because of its lower heat production ${ }^{13,17}$. This avoided the thermal effect of collagen extensibility and consequent scar destruction. Rats were chosen as the experimentation animals given that these animals are easily obtained and managed, which facilitated all the procedures. Nirgiotis, Hennessey \& Andrassy ${ }^{18}$, in an experimental study using rats subjected to stress and an arginine-free diet, mentioned that the animals presented deficiency in collagen deposition and lower tensile strength in the scar. It has also been described in the literature that malnutrition affects the immune system. In particular, it reduces immunity, leukocyte counts and leukocyte function. Such alterations contribute towards increasing the susceptibility to infections ${ }^{17}$. Reddy, Stehno-Bittel \& Enwemeka ${ }^{19}$ also described positive results from ultrasound regarding collagen synthesis and the stimulation of proliferative cells, which suggested growth of conjunctive tissue during the tissue repair process. In the present study, the results found in group G3 (animals in a normal nutritional state that underwent ultrasound therapy) demonstrated coherence with the findings described in the literature ${ }^{14}$. In these, after the third day with the injury, the fibroblasts were found to start to produce fibrils that randomly aggregated in the extracellular space, thus aiding in protecting the tendon tissue against the forces applied at the start of the healing process ${ }^{11}$. Studies have reported that ultrasound provides effective assistance for releasing growth factors, which may explain the acceleration in the tissue repair process ${ }^{6}$. The results from this study corroborate those of Reddy, Stehno-Bittel \& Enwemeka ${ }^{19}$ and also show that, throughout the stages of the experiment, the appearance of fibrosis and increase in collagen were statistically significant in the groups treated with ultrasound. This indicates that the ultrasound acted to increase collagen deposition and scar tissue formation. The results from the present study emphasize the importance of ultrasound therapy and demonstrate that, even without statistically significant results, there was improvement and leveling of the inflammatory events in the group of malnourished animals that received ultrasound treatment. These results resemble those found by other 
authors who have reported satisfactory effects from therapeutic ultrasound during the repair process ${ }^{2,5,7,20}$.

\section{Conclusion}

The therapeutic ultrasound was shown to be effective for tendon repair, even in malnourished animals with a retarded healing process, although animals with normal nutrition presented more satisfactory responses in the healing process than did either the treated or untreated malnourished groups.

\section{References}

1. Curwin SL. Biomechanics of tendon and effects of immobilization. Foot Ankle Clin. 1997;2(3):371-87.

2. Enwemeka CS. The effects of therapeutic ultrasound on tendon healing. Am J Phys Med Rehabil. 1989;68(6): 283-7.

3. Yue DK, Mclennan S, Marsh M, Mai YW, Spaliviero J, Delbridge L. et al. Effects of experimental diabetes, uremia and malnutrition on wound healing. Diabetes. 1987;36:295-9.

4. Silveira IS, Raiser AG, Polydoro AS. Efeitos da dieta protéica na cicatrização de fraturas distais de fêmur imobilizadas com pinos intramedulares em cão. Acta Cir Bras. 1997;12(3):178-81.

5. Kitchen SS, Partridge CJ. A review of therapeutic ultrasound. Physiother. 1990;76(10):593-600.

6. Young SR, Dyson M. The effect of therapeutic ultrasound on angiogenesis. Ultrasound Med Biol. 1990;16(3): 261-9.

7. Dyson M.; Suckling J. Stimulation of tissue repair by therapeutic ultrasound. Physiotherapy. .64(4):105-8, 1978.

8. McDiarmid TP, Burns N. Ultrasound and the treatment of pressure sores. Physiother. 1985; 71(2):66-70.
9. Heckman, JD. Ryaby JP. Acceleration of tibial fracturehealing by non-invasive, low-intensity pulsed ultrasound. J Bone Joint Surg Am. 1994;76(1):26-34.

10. Young SR, Dyson M. Macrophage responsiveness to therapeutic ultrasound. Ultrasound Med Biol. 1990;16(8):809-16.

11. Frieder S, Weisberg J. A pilot study: the therapeutic effect of ultrasound following partial rupture of Achilles tendons in male rats. J Orthop Sports Phys Ther. 1988;10:39-46.

12. Dyson, M. Mechanisms involved in therapeutic ultrasound. Physioter. 1987;73(3):116-20.

13. Roberts M, Rutherford JH, Harris D. The effect of ultrasound on flexor tendon repairs in the rabbit. Hand. 1982;14(1):17-20.

14. Collins CE, Kershaw J, Brockington S. Effect of nutritional supplements on wound healing in home-nursed elderly: A randomized trial. Nutrition. 2005;21(2):147-55.

15. Caregaro L, Alberino F, Amodio P, Merkel C, Bolognesi M, Angeli P, Gatta A. Malnutrition in alcoholic and virusrelated cirrhosis. Am J Clin Nutr. 1996;63(4):602-9.

16. Lansdown AB. Nutrition 1: a vital consideration in the management of skin wounds. Br J Nurs. 2004; 13(19): $22-$ 8.

17. Dyson M. Non-thermal cellular effects of ultrasound. $\mathrm{Br}$ J Cancer Suppl. 1982;45(5):165-71.

18. Nirgiotis JG, Hennessey PJ, Andrassy RJ. The effects of an arginine-free enteral diet on wound healing and immune function in the postsurgical rat. J Pediatr Surg. 1991; 26(8):936-41.

19. Reddy GK, Stehno-Bittel L, Enwemeka CS. Glycationinduced matrix stability in the rabbit achilles tendon. Arch Biochem Biophys. 2002;399(2):174-80.

20. Dyson M, Pond JB, Joseph J, Warwick R. The stimulation of tissue regeneration by means of ultrasound. Clin Sci. 1968; 35(2):273-85.

\section{Correspondence:}

Paulo de Tarso Camillo de Carvalho

Rua Abricó do Pará, 146, Carandá Bosque.

79032-423 - Campo Grande - MS - Brazil

e-mail:ptpaulo@terra.com.br
Conflict of interest: None Financial source: Manoel de Barros Foundation

\section{How to cite this article:}

Carvalho PTC, Silva IS, Reis FA, Belchior ACG, Aydos RD, Facco GG, Dourado DM. Histological study of tendon healing in malnourished Wistar rats treated with ultrasound therapy. Acta Cir Bras. [serial on the Internet] $2006 ; 21$ Suppl 4. Available from URL: http://www.scielo.br/acb.

* Color figures available from www.scielo.br/acb 